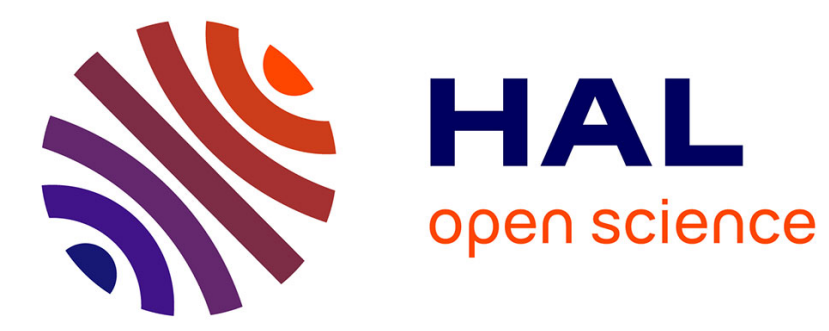

\title{
Effect of green manuring on the yield of sweet corn
}

\author{
Ilhan Turgut, Ugur Bilgili, Ahmet Duman, Esvet Acikgoz
}

\section{To cite this version:}

Ilhan Turgut, Ugur Bilgili, Ahmet Duman, Esvet Acikgoz. Effect of green manuring on the yield of sweet corn. Agronomy for Sustainable Development, 2005, 25 (4), pp.433-438. hal-00886304

\section{HAL Id: hal-00886304 https://hal.science/hal-00886304}

Submitted on 1 Jan 2005

HAL is a multi-disciplinary open access archive for the deposit and dissemination of scientific research documents, whether they are published or not. The documents may come from teaching and research institutions in France or abroad, or from public or private research centers.
L'archive ouverte pluridisciplinaire HAL, est destinée au dépôt et à la diffusion de documents scientifiques de niveau recherche, publiés ou non, émanant des établissements d'enseignement et de recherche français ou étrangers, des laboratoires publics ou privés. 


\title{
Effect of green manuring on the yield of sweet corn
}

\author{
Ilhan TuRgut, Ugur BILgILI, Ahmet Duman, Esvet ACIKGOZ* \\ Department of Field Crops, Faculty of Agriculture, Uludag University, 16059, Gorukle Campus, Bursa, Turkey
}

(Accepted 10 May 2005)

\begin{abstract}
Experiments were conducted on a clay soil to assess the effects of green manuring of three annual legumes and nitrogen fertilization on sweet corn (Zea mays var. saccharata Sturt.), during three growing seasons (2001-2003). The green manuring legumes were field pea (Pisum sativum L.), common vetch (Vicia sativa L.) and faba bean (Vicia faba L.) N fertilization ranged from 0 to $360 \mathrm{~kg} \mathrm{ha}^{-1}$. On a three-year average, field pea (3065 kg ha $\left.{ }^{-1}\right)$ and common vetch $\left(2647 \mathrm{~kg} \mathrm{ha}^{-1}\right)$ consistently had higher aboveground dry matter yields than faba bean $\left(1307 \mathrm{~kg} \mathrm{ha}^{-1}\right)$. Field pea and common vetch had $\mathrm{N}$ contents of 68.7 and $54.0 \mathrm{~kg} \mathrm{ha}^{-1}$, respectively, in aboveground dry matter in the spring. The average $\mathrm{N}$ content of faba bean was only $30.0 \mathrm{~kg} \mathrm{ha}^{-1}$. Green manuring treatments and $\mathrm{N}$ fertilization had different effects on yield components of sweet corn. Average ear yields of corn were significantly greater in plots receiving green manuring $\left(15127 \mathrm{~kg} \mathrm{ha}^{-1}\right)$ than those without green manuring $\left(13826 \mathrm{~kg} \mathrm{ha}^{-1}\right)$. The ear yields following green manuring legumes were 33-39\% higher compared with fallow under unfertilized conditions. Ear yield of corn generally increased with an increasing rate of $\mathrm{N}$ fertilizer. Although the combined use of green manuring and 240 and $360 \mathrm{~kg} \mathrm{ha}^{-1} \mathrm{~N}$ fertilization produced high ear yields, there were no statistically significant increases beyond $120 \mathrm{~kg}$ ha ${ }^{-1} \mathrm{~N}$.
\end{abstract}

sweet corn / Zea mays var. saccharata / green manuring / field pea / common vetch / faba bean / nitrogen fertilization

\section{INTRODUCTION}

Forage legumes are widely used as green manure crops to improve soil fertility and to increase the yield of subsequent crops in rotations. They are an effective source of $\mathrm{N}$ and also enhance the cycling of phosphorus and other nutrients for subsequent crops (Kahnt, 1983, Haynes et al., 1993). In addition to the $\mathrm{N}$ added to the soil when legumes are turned under, green manures may increase organic matter, lower soil bulk density, increase soil microbiological biomass and increase infiltration of water (McGuire et al., 1998). Increased availability and low cost have increased the use of $\mathrm{N}$ fertilizer and rapidly decreased the use of green manure legumes in cropping systems in past decades (Badaruddin and Meyer, 1990). However, with renewed interest in legumes as green manures, the effects of green manures on the following crops have received more attention in different cropping systems.

Limited information is at present available on the effects of green manuring on the subsequent corn yield. Adams et al. (1970) found that corn yields after annual green manure crops were greater than continuous corn, even though as much as $180 \mathrm{~kg} \mathrm{ha}^{-1} \mathrm{~N}$ had been applied to the soil. Mitchell and Teel (1977) found that no-tillage corn grown without $\mathrm{N}$ fertilizer following hairy vetch (Vicia villosa Roth.) and crimson clover mixtures yielded as high as corn growing with $112 \mathrm{~kg} \mathrm{ha}^{-1} \mathrm{~N}$. Similarly, the $\mathrm{N}$ supplied by a hairy vetch cover crop was suf- ficient to produce corn yields approximately equivalent to $170 \mathrm{~kg} \mathrm{ha}^{-1}$ fertilizer $\mathrm{N}$ (Utomo et al., 1990). Ebelhar et al. (1984) killed annual legume cover crops with herbicides. They found that hairy vetch supplied biologically fixed $\mathrm{N}$ equivalent to approximately 90 to $100 \mathrm{~kg} \mathrm{ha}^{-1}$ fertilizer annually to the corn. Big flower vetch (Vicia grandifolia W. Koch.) and crimson clover provided much less $\mathrm{N}$ than hairy vetch in this study.

Sweet corn (Zea mays var. saccharata Sturt.) acreage has increased in the south Marmara region in recent years for the fresh market or freezing and canning purposes. The ears are generally harvested by hand in the field and then kernels are cut in the factories. The stover is ensiled alone or in mixtures with the other crops. Very limited data have been published in recent years specifically on the role of green manuring legume crops in sweet corn production. The mild and moist winter climate of the Bursa Province is very suitable for the production of winter annual legume cover crops for green manuring. In this study, three annual legume green manure crops, namely field pea, common vetch and faba bean were grown in the fall and winter growing periods and incorporated into the soil before planting sweet corn in late spring. The subsequent effects of these legumes on the yield and yield components of a sweet corn crop with the combination of four levels of $\mathrm{N}$ fertilization were investigated for three years in Bursa Province, with a Mediterranean-type climate.

\footnotetext{
* Corresponding author: esvet@uludag.edu.tr
} 
Table I. Soil characteristics of experimental plots.

\begin{tabular}{lcccccccc}
\hline Years & $\begin{array}{c}\text { Clay } \\
(\%)\end{array}$ & $\begin{array}{c}\text { Silt } \\
(\%)\end{array}$ & $\begin{array}{c}\text { Sand } \\
(\%)\end{array}$ & $\begin{array}{c}\mathrm{P}_{2} \mathrm{O}_{5} \\
\left(\mathrm{~kg} \mathrm{ha}^{-1}\right)\end{array}$ & $\begin{array}{c}\mathrm{K}_{2} \mathrm{O} \\
\left(\mathrm{kg} \mathrm{ha}^{-1}\right)\end{array}$ & $\begin{array}{c}\mathrm{CaCO}_{3} \\
(\%)\end{array}$ & $\begin{array}{c}\text { Organic matter } \\
(\%)\end{array}$ \\
\hline 2001 & 42.8 & 18.4 & 38.8 & 86 & 1230 & 0 & 1.9 \\
2002 & 38.4 & 20.0 & 41.6 & 57 & 850 & 1.6 & 1.6 \\
2003 & 45.8 & 18.6 & 35.6 & 67 & 720 & 1.6 & 2.4 \\
Aver. & 42.3 & 19.0 & 38.7 & 70 & 933 & 1.1 & 7.3 \\
\hline
\end{tabular}

Table II. Monthly rainfall (mm), temperature $\left({ }^{\circ} \mathrm{C}\right)$ and relative humidity (\%) in 2001, 2002 and 2003 with long-term averages (1928-1996).

\begin{tabular}{|c|c|c|c|c|c|c|}
\hline \multirow[b]{2}{*}{ Months } & \multicolumn{3}{|c|}{2001} & \multicolumn{3}{|c|}{2002} \\
\hline & Rainfall & Temp.* & $\mathrm{RH}^{* *}$ & Rainfall & Temp. & $\mathrm{RH}$ \\
\hline May & 65.0 & 18.2 & 65.1 & 50.5 & 17.3 & 67.9 \\
\hline June & 16.7 & 23.6 & 48.2 & 25.2 & 23.0 & 62.1 \\
\hline July & 1.7 & 27.7 & 50.5 & 49.9 & 26.7 & 64.4 \\
\hline \multirow[t]{2}{*}{ August } & 13.1 & 26.4 & 52.8 & 31.1 & 24.6 & 65.2 \\
\hline & \multicolumn{3}{|c|}{2003} & \multicolumn{3}{|c|}{ Long-term } \\
\hline Months & Rainfall & Temp. & $\mathrm{RH}$ & Rainfall & Temp. & $\mathrm{RH}$ \\
\hline May & 45.7 & 18.8 & 67.7 & 50.7 & 17.8 & 69.4 \\
\hline June & 2.4 & 23.8 & 54.8 & 31.0 & 22.1 & 61.3 \\
\hline July & - & 25.3 & 56.3 & 24.2 & 24.5 & 59.0 \\
\hline August & - & 25.6 & 58.1 & 18.8 & 24.1 & 60.5 \\
\hline
\end{tabular}

* Temp. $=$ temperature,$* * \mathrm{RH}=$ relative humidity.

\section{MATERIALS AND METHODS}

The experiments were conducted during three consecutive growing years (2001-2003) at the Uludag University Research Farm, near Bursa (40 $11^{\prime}$ 'North, 29 04' East), $70 \mathrm{~m}$ above sea level. The soil on the site is classified as Vertisol typic habloxrert. The soil was clay loam, slightly alkaline $(\mathrm{pH}=7.3)$, rich in potassium $\left(933 \mathrm{~kg} \mathrm{ha}^{-1}\right)$, medium in phosphorus $\left(70 \mathrm{~kg} \mathrm{ha}^{-1}\right)$ and containing $2.0 \%$ organic matter (Tab. I). Long-term average total precipitation is $720 \mathrm{~mm}^{\circ}$ ear $^{-1}$, the mean temperature for the whole year is $15^{\circ} \mathrm{C}$, and relative humidity is $68 \%$. Precipitation during the experiment's growing period (MayAugust) for the long term in 2001, 2002 and 2003 was 125, 96, 157 , and $48 \mathrm{~mm}$, respectively. The average temperature of the main growing months of the crop (June-August) varied from 23 to $28{ }^{\circ} \mathrm{C}$ during the experimental years (Tab. II).

The experimental plot design was a split plot with three replications. Three green manuring crops; field pea (Pisum sativum L.), common vetch (Vicia sativa L.) and faba bean (Vicia faba L.) and fallow (control) were the main plots and four different levels of nitrogen fertilization $(0,120,240$ and $360 \mathrm{~kg} \mathrm{ha}^{-1}$ ) were sub-plot treatments.

The precrop was sunflower (Helianthus annuus L.) in all experimental years. After harvesting the sunflower in September, the plots were ploughed and then harrowed. Before seeding, $30 \mathrm{~kg} \mathrm{ha}^{-1}$ each of $\mathrm{N}$ and $\mathrm{P}$ were applied into the seedbed. Green manuring crops were seeded on 13 Nov. 2000, 12 Dec. 2001 and 04 Nov. 2002. Seeding rates were $120 \mathrm{~kg} \mathrm{ha}^{-1}$ for common vetch (var. Emir), $150 \mathrm{~kg} \mathrm{ha}^{-1}$ for pea (var. P98) and $300 \mathrm{~kg} \mathrm{ha}^{-1}$ for faba bean (var. Common), at row spacings of $14 \mathrm{~cm}, 14 \mathrm{~cm}$ and $30 \mathrm{~cm}$, respectively. Common vetch and field pea were seeded with a plot drill while faba bean was seeded by hand. Green manuring crops were ploughed down at the full flowering stage, usually in early April, at least 20 days before corn seeding in all experimental years. Before plowing, four replicated $1-\mathrm{m}^{2}$ areas of each green manuring crop were cut at the soil surface and then total aboveground dry matter yield was determined. The roots of those sampled areas were removed from the 0-30 cm soil depth, washed and weighed. Harvested herbages and roots were redistributed in the harvested area, with the exception of the small samples. Aboveground biomass and root samples were dried at $70{ }^{\circ} \mathrm{C}$ for $48 \mathrm{~h}$ to determine the dry matter yield of green manuring crops. Those samples were stored for $\mathrm{N}$ analysis.

Before corn seeding, $100 \mathrm{~kg} \mathrm{ha}^{-1}$ each of $\mathrm{P}$ and $\mathrm{K}$ was incorporated into the disked and harrowed soil. Sweet corn var. Jubilee was seeded on 21 May 2001, 24 May 2002 and 4 June 2003 with a plot drill. Sub-plot size was $2.6 \times 5.0 \mathrm{~m}=13.0 \mathrm{~m}^{2}$. Each plot consisted of four rows. Row spacing was $65 \mathrm{~cm}$. Intra-row spacing was $25 \mathrm{~cm}$, and plant population was 61540 plants $^{-1}$. The corn crop was overseeded at a double rate and then thinned by hand after emergence to achieve the desired target plant density. Gesaprim $500 \mathrm{SC}$ (Atrazine) was applied at a rate of $3.0 \mathrm{~kg}$ a.i. ha ${ }^{-1}$ just after seeding for weed control, and Karate EC 5 (Lambda-cyhalothrin) was sprayed at a rate of $300 \mathrm{cc}$ a.i. ha ${ }^{-1}$ for European corn borer (Ostrinia nubilalis) control. Sprinkler 
Table III. Total aboveground and root dry matter yield $\left(\mathrm{kg} \mathrm{ha}^{-1}\right)$ and $\mathrm{N}$ content $\left(\mathrm{kg} \mathrm{ha}^{-1}\right)$ incorporated into the soil in green manuring crops.

\begin{tabular}{|c|c|c|c|c|c|c|c|c|}
\hline \multirow[b]{2}{*}{ Crops } & \multicolumn{2}{|c|}{$2000-2001$} & \multicolumn{2}{|c|}{$2001-2002$} & \multicolumn{2}{|c|}{$2002-2003$} & \multicolumn{2}{|c|}{ Three-year average } \\
\hline & Dry matter & N Content & Dry matter & N Content & Dry matter & N Content & Dry matter & N Content \\
\hline \multicolumn{9}{|c|}{ Aboveground } \\
\hline Field pea & $1166 c^{*}$ & $26.9 \mathrm{~b}$ & $4380 a$ & $100.7 \mathrm{a}$ & $3648 \mathrm{a}$ & $77.7 \mathrm{a}$ & $3065 a$ & $68.7 \mathrm{a}$ \\
\hline Common vetch & $2872 \mathrm{a}$ & $57.2 \mathrm{a}$ & $2686 b$ & $59.9 \mathrm{~b}$ & $2383 b$ & $45.0 \mathrm{~b}$ & $2647 \mathrm{a}$ & $54.0 \mathrm{~b}$ \\
\hline Faba bean & $1497 b$ & $28.5 b$ & $1440 \mathrm{c}$ & $36.9 b$ & $983 c$ & $24.0 \mathrm{c}$ & $1307 b$ & $30.0 \mathrm{c}$ \\
\hline \multicolumn{9}{|c|}{ Roots } \\
\hline Field pea & $52 c$ & $0.75 b$ & $313 a$ & $4.16 \mathrm{a}$ & $58 \mathrm{~b}$ & $0.86 \mathrm{~b}$ & $141 \mathrm{~b}$ & $2.00 \mathrm{~b}$ \\
\hline Common vetch & $112 \mathrm{~b}$ & $1.32 \mathrm{~b}$ & $161 \mathrm{~b}$ & $2.38 b$ & $140 \mathrm{a}$ & $1.97 \mathrm{a}$ & $138 \mathrm{~b}$ & $1.88 \mathrm{~b}$ \\
\hline Faba bean & $207 \mathrm{a}$ & $2.88 \mathrm{a}$ & $450 \mathrm{a}$ & $7.70 \mathrm{a}$ & $126 \mathrm{a}$ & $2.07 \mathrm{a}$ & $261 \mathrm{a}$ & $4.12 \mathrm{a}$ \\
\hline
\end{tabular}

* Means followed by the same letter are not significantly different at the 0.05 level using the LSD test.

irrigation was done five times in all experimental years when necessary. Half of the nitrogen was applied before seeding, and the remaining nitrogen was topdressed when the plants attained 40 to $50 \mathrm{~cm}$ in height.

Corn ears were harvested by hand when kernels were at the milk dough stage on 16 August 2001, 16 August 2002 and 28 August 2003, respectively. Plant height, ear height and ears per plant were measured on a randomly taken 10 plants per each plot. A sample of 10 ears per plot was selected and ear weight, ear length, ear diameter, rows per ear, seeds per row and seeds per ear were measured. Ears were harvested from 5.0-m lengths of the two center rows in each plot by hand for fresh ear yield determination. The moisture content of the kernel was approximately $70 \%$ at the harvesting stage.

Every year, the nitrogen concentration of herbage and root samples was determined in duplicate by the micro-Kjeldahl procedure for each green manuring crop.

Analysis of variance was performed on morphological measurements and yield data using the MINITAB (University of Texas at Austin) and MSTAT-C (Version 2.1 Michigan State University, 1991) programs. The significance of main effects was determined by the F test. Differences in treatment means were detected by the LSD test $(0.05)$ for comparisons.

\section{RESULT AND DISCUSSION}

The aboveground and root dry matter yields, and $\mathrm{N}$ incorporated into the soil of green manuring legumes are shown in Table III. Both dry matter yields varied significantly among legumes in all experimental years. Aboveground dry matter yield by full flowering averaged 3065,2647 and $1307 \mathrm{~kg} \mathrm{ha}^{-1}$ for field pea, common vetch and faba bean, respectively. Despite poor establishment in the 2000-2001 season, probably due to poor seed quality, field pea tended to be superior due to its large dry matter production. Common vetch was the more productive green manure crop and its dry matter yields were more consistent than field pea and faba bean. The three-year average dry matter yields of field pea and common vetch were nearly identical and the difference was not statistically significant. In close agreement with our previous studies (Aydogdu and Acikgoz, 1995; Uzun and Acikgoz, 1998; Uzun et al., 2005), common vetch and field pea seemed very promising for green manuring legumes under the humid and mild growing conditions of the winter and early spring in the region. Schoth and McKee (1966) also indicated that Vicia and Pisum species are widely grown in temperate areas of the world for green manure without interfering with the regular crop. Faba bean was the lowest dry-matter yielding legume in all experimental years due to inadequate growth and cold damage during winter and early springtime.

$\mathrm{N}$ content in aboveground and root dry matter of all legume species was high for all years, with a $\mathrm{N}$ concentration of 2.04 to $2.30 \%$ in aboveground and of 1.36 to $1.58 \%$ in root dry matter. $\mathrm{N}$ yields of aboveground dry matter were 68.7, 54.0 and $30.0 \mathrm{~kg} \mathrm{ha}^{-1}$ for field pea, common vetch and faba bean, respectively. Although field pea returned slightly more dry matter to the soil than common vetch, its $\mathrm{N}$ contribution was significantly more than that of common vetch $\left(68.7\right.$ vs. $\left.54.0 \mathrm{~kg} \mathrm{ha}^{-1}\right)$. Faba bean was the poorest among the green manure crops used. Its green manure returned, on a three-year average, $30 \mathrm{~kg} \mathrm{ha}^{-1} \mathrm{~N}$ to the soil in aboveground yield, which was $14 \mathrm{~kg} \mathrm{ha}^{-1}$ lower than common vetch and $38.7 \mathrm{~kg} \mathrm{ha}^{-1}$ lower than field pea.

Mean legume root dry matter yields were lowest in common vetch $\left(138 \mathrm{~kg} \mathrm{ha}^{-1}\right)$ and the highest in faba bean $\left(261 \mathrm{~kg} \mathrm{ha}^{-1}\right)$. On a three-year average, there was no significant difference between common vetch and field pea. $\mathrm{N}$ yields of the roots were also lower than those of the aboveground matter (Tab. III). As known, the roots of annual legumes, for example, pea roots, may extend to a depth of $1 \mathrm{~m}$ or more (Davies et al., 1985). In our study, significant loss of root pieces and nodules may have occurred during sampling, and only a fraction of the root biomass was extracted. Moreover, roots and nodules were not sampled below the $30 \mathrm{~cm}$ depth. Therefore, the actual root dry matter yields of green manuring crops may be higher than our findings. However, despite all possible losses, it is clear that the root dry matter yield and $\mathrm{N}$ contribution of those legumes were much lower than that of aboveground matter. Very limited information is presently available on the root yield of annual legumes. In comparison with our studies, our root dry matter yields of pea were similar to previous reports (Biederbeck et al., 1993). They showed that pea root yield in $30 \mathrm{~cm}$ soil depth varied 
Table IV. Effects of green manuring treatments and nitrogen fertilization $\left(\mathrm{kg} \mathrm{ha}^{-1}\right)$ on the yield and yield components of subsequent sweet corn (average of 3 years).

\begin{tabular}{|c|c|c|c|c|c|c|c|c|c|c|}
\hline Crops & $\begin{array}{l}\text { Plant height } \\
(\mathrm{cm})\end{array}$ & $\begin{array}{c}\text { Ear } \\
\text { height }(\mathrm{cm})\end{array}$ & $\begin{array}{l}\text { Ear length } \\
(\mathrm{cm})\end{array}$ & $\begin{array}{l}\text { Ear diameter } \\
(\mathrm{mm})\end{array}$ & $\begin{array}{l}\text { Rows } \\
\text { per ear }\end{array}$ & $\begin{array}{l}\text { Seeds } \\
\text { per row }\end{array}$ & $\begin{array}{l}\text { Seeds } \\
\text { per ear }\end{array}$ & $\begin{array}{c}\text { Ears } \\
\text { per plant }\end{array}$ & $\begin{array}{l}\text { Ear weight } \\
\text { (g/plant) }\end{array}$ & $\begin{array}{c}\text { Ear yield } \\
\text { (kg/ha) }\end{array}$ \\
\hline Fallow & 124.1 & $45.9 c^{1}$ & $20.0 \mathrm{~b}$ & $42.1 \mathrm{a}$ & 16.4 & $40.7 \mathrm{a}$ & 669.2 & $1.24 \mathrm{a}$ & $175.3 b$ & $13826 b$ \\
\hline Field pea & 123.8 & $49.9 b$ & $20.5 \mathrm{a}$ & $42.3 \mathrm{a}$ & 16.5 & $41.0 \mathrm{a}$ & 680.9 & $1.26 \mathrm{a}$ & $185.6 \mathrm{a}$ & $15591 \mathrm{a}$ \\
\hline Common vetch & 129.5 & $53.0 \mathrm{a}$ & $20.2 \mathrm{ab}$ & $42.8 \mathrm{a}$ & 16.7 & $40.5 \mathrm{ab}$ & 678.3 & $1.28 \mathrm{a}$ & $191.9 \mathrm{a}$ & $15764 a$ \\
\hline Faba bean & 122.5 & $50.3 b$ & $19.4 \mathrm{c}$ & $40.1 b$ & 16.4 & $39.7 b$ & 654.8 & $1.14 \mathrm{~b}$ & $168.8 \mathrm{~b}$ & $14027 b$ \\
\hline \multicolumn{11}{|l|}{ N Doses } \\
\hline 0 & 124.2 & $47.8 \mathrm{~b}$ & $19.4 \mathrm{c}$ & 41.0 & 16.3 & $39.5 b$ & $643.4 b$ & 1.20 & $166.3 b$ & $12918 b$ \\
\hline 120 & 122.7 & $50.5 \mathrm{a}$ & $20.1 b$ & 41.8 & 16.5 & $40.7 \mathrm{a}$ & $676.9 \mathrm{a}$ & 1.22 & $181.8 \mathrm{a}$ & $15117 \mathrm{a}$ \\
\hline 240 & 127.4 & $51.3 \mathrm{a}$ & $20.1 b$ & 42.1 & 16.5 & $40.5 \mathrm{a}$ & $673.8 \mathrm{a}$ & 1.23 & $185.2 \mathrm{a}$ & $15534 \mathrm{a}$ \\
\hline \multirow[t]{4}{*}{360} & 125.5 & $49.6 \mathrm{a}$ & $20.5 \mathrm{a}$ & 42.5 & 16.7 & $41.1 \mathrm{a}$ & $689.1 \mathrm{a}$ & 1.27 & $188.3 \mathrm{a}$ & $15640 \mathrm{a}$ \\
\hline & \multicolumn{10}{|c|}{ Coefficient of Variation (\%) } \\
\hline & 10.2 & 7.7 & 4.6 & 6.5 & 5.1 & 4.8 & 6.8 & 13.4 & 11.5 & 7.9 \\
\hline & \multicolumn{10}{|c|}{ F test } \\
\hline Treatment (A) & Ns & $* *$ & $* *$ & $* *$ & Ns & $*$ & Ns & $* *$ & $* *$ & $* *$ \\
\hline N Dose (B) & Ns & $* *$ & $* *$ & Ns & Ns & $* *$ & $* *$ & Ns & $* *$ & $* *$ \\
\hline$A \times B$ & Ns & Ns & Ns & Ns & Ns & Ns & Ns & Ns & * & $* *$ \\
\hline
\end{tabular}

${ }^{1}$ Means followed by the same letter are not significantly different at the 0.05 level using the LSD test, *** F-test significant at $P \leq 0.05$ and $P \leq 0.01$, respectively. Ns, not significant.

from 100 to $303 \mathrm{~kg} \mathrm{ha}^{-1}$, and averaged $187 \mathrm{~kg} \mathrm{ha}^{-1}$. Our study showed that the average $\mathrm{N}$ contribution of aboveground matter was approximately 19 times higher than that of the roots (50.9 vs. $2.7 \mathrm{~kg} \mathrm{ha}^{-1}$ ) in the annual green manuring crops used. Similarly, Mitchell and Teel (1977) indicated that the total N content of hairy vetch and crimson clover mixtures with oat (Avena sativa L.), rye (Secale cereale L.) or ryegrass (Lolium sp.) averaged 159.7 and $20.1 \mathrm{~kg} \mathrm{ha}^{-1}$ in root and top growth, respectively, indicating about $90 \%$ of $\mathrm{N}$ yield derived from top growth.

There were no significant interactions between green manure treatments and $\mathrm{N}$ doses in most yield components; therefore, we were mainly interested in an average trend over time in the green manures and $\mathrm{N}$ pools. The data are presented as the means of three years in Table IV. Green manuring treatments and $\mathrm{N}$ fertilization had different effects on the plant characteristics measured. Both green manuring and $\mathrm{N}$ fertilization regimes had little effect on plant height, but ears were generally set higher above the ground in plots receiving green manuring and fertilized with $\mathrm{N}$ than fallow plots. Although some differences were statistically significant, ear length and diameter were not affected greatly by green manuring or $\mathrm{N}$ fertilization treatments. Green manure crops also had little, but a significant effect, on ear weight. There were small but significant increases in ear weight with increasing $\mathrm{N}$ fertilization. Green manuring and $\mathrm{N}$ fertilization regimes had little effect on rows per ear and seeds per row. $\mathrm{N}$ fertilization greatly affected seeds per ear. Seeds per ear was significantly higher in $\mathrm{N}$ fertilized plots than control plots. Number of ears per plant varied slightly among green manuring treatments, but it was not significantly different due to $\mathrm{N}$ fertilization.
In general, ear yields of corn were significantly greater in plots receiving green manuring than those without green manuring. Ear yield was $13826 \mathrm{~kg} \mathrm{ha}^{-1}$ in fallow plots, whereas following green manure legumes it averaged $15127 \mathrm{~kg} \mathrm{ha}^{-1}$, regardless of $\mathrm{N}$ rates. Also, ear yields increased significantly when $\mathrm{N}$ fertilizers were applied in fallow treatments. The ear yield of fallow (10 $206 \mathrm{~kg} \mathrm{ha}^{-1}$ ) increased with increasing $\mathrm{N}$ doses and maximized at $360 \mathrm{~kg} \mathrm{ha}^{-1} \mathrm{~N}$ treatment $\left(15808 \mathrm{~kg} \mathrm{ha}^{-1}\right)$. There was an increase of 37, 51 and 55\% with 120, 240 and $360 \mathrm{~kg} \mathrm{ha}^{-1} \mathrm{~N}$ treatments in fallow plots (Tab. V).

A significant green manuring treatment $\times \mathrm{N}$ fertilization interaction was detected in ear yield at the 0.01 level. The ear yields following green manuring legumes were significantly higher than following fallow when unfertilized in all experimental years and combined years. According to the three-year average, ear yield was $14213 \mathrm{~kg} \mathrm{ha}^{-1}$ following green manuring with field pea, common vetch $\left(13633 \mathrm{~kg} \mathrm{ha}^{-1}\right)$ and faba bean $\left(13620 \mathrm{~kg} \mathrm{ha}^{-1}\right)$, which were significantly more than following fallow (10 $206 \mathrm{~kg} \mathrm{ha}^{-1}$ ). In other words, there were 39 , 34 and $33 \%$ increases compared with fallow under unfertilized conditions. There was no statistically significant difference in ear yield between green manuring crops (Tab. V).

On a three-year average, green manuring treatments appeared to increase corn yield with $\mathrm{N}$ fertilizers. Field pea and common vetch green manuring crops showed significant ear yield advantages in $\mathrm{N}$ fertilization treatments, as found by Grewal et al. (1992), who indicated that combined use of green manuring and $\mathrm{N}$ fertilization produced the highest corn yield. Significantly higher ear yields were obtained with $120 \mathrm{~kg} \mathrm{ha}^{-1} \mathrm{~N}$ dose than unfertilized field pea and common vetch green 
Table V. Green manure crops $\times$ nitrogen dose interactions for ear yield $\left(\mathrm{kg} \mathrm{ha}^{-1}\right)$.

\begin{tabular}{|c|c|c|c|c|}
\hline \multirow{3}{*}{ Crops } & \multicolumn{4}{|c|}{ Nitrogen doses $\left(\mathrm{kg} \mathrm{ha}^{-1}\right)$} \\
\hline & 0 & 120 & 240 & 360 \\
\hline & \multicolumn{4}{|c|}{ 2000-2001 } \\
\hline Fallow & 11490h* & $14370 \mathrm{e}-\mathrm{g}$ & $13920 \mathrm{~g}$ & $15420 \mathrm{~b}-\mathrm{g}$ \\
\hline Field pea & $15890 \mathrm{a}-\mathrm{e}$ & $16510 \mathrm{a}-\mathrm{c}$ & $17180 \mathrm{a}$ & $16620 \mathrm{ab}$ \\
\hline Common vetch & $15020 \mathrm{c}-\mathrm{g}$ & $15740 a-f$ & $16290 \mathrm{a}-\mathrm{d}$ & $15480 \mathrm{~b}-\mathrm{g}$ \\
\hline \multirow[t]{2}{*}{ Faba bean } & $14290 \mathrm{e}-\mathrm{g}$ & $14720 \mathrm{~d}-\mathrm{g}$ & $14240 f g$ & $14210 f g$ \\
\hline & \multicolumn{4}{|c|}{ 2001-2002 } \\
\hline Fallow & $9962 \mathrm{~g}$ & $14440 \mathrm{c}-\mathrm{e}$ & $15010 \mathrm{~b}-\mathrm{d}$ & $16540 \mathrm{ab}$ \\
\hline Field pea & $12370 \mathrm{f}$ & $13950 \mathrm{~d}-\mathrm{f}$ & $15080 \mathrm{~b}-\mathrm{d}$ & $17380 \mathrm{a}$ \\
\hline Common vetch & $9859 \mathrm{~g}$ & 16310ab & $16310 \mathrm{a}-\mathrm{c}$ & 16610ab \\
\hline \multirow[t]{2}{*}{ Faba bean } & $13350 \mathrm{~d}-\mathrm{f}$ & $14120 \mathrm{~d}-\mathrm{f}$ & $12770 \mathrm{ef}$ & $12930 \mathrm{ef}$ \\
\hline & \multicolumn{4}{|c|}{$2002-2003$} \\
\hline Fallow & $9170 \mathrm{f}$ & $12990 \mathrm{e}$ & 17140ab & $15470 \mathrm{a}-\mathrm{d}$ \\
\hline Field pea & $14390 \mathrm{c}-\mathrm{e}$ & $16030 \mathrm{a}-\mathrm{c}$ & $15950 a-c$ & $15750 \mathrm{a}-\mathrm{c}$ \\
\hline Common vetch & $16020 a-c$ & $17200 \mathrm{ab}$ & $17710 \mathrm{a}$ & $16620 a-c$ \\
\hline \multirow[t]{2}{*}{ Faba bean } & 13220de & $15010 \mathrm{~b}-\mathrm{e}$ & $14810 \mathrm{~b}-\mathrm{e}$ & $14650 \mathrm{c}-\mathrm{e}$ \\
\hline & \multicolumn{4}{|c|}{ Three-year average } \\
\hline Fallow & $10206 \mathrm{f}$ & $13935 \mathrm{e}$ & $15355 \mathrm{~cd}$ & $15808 \mathrm{abc}$ \\
\hline Field pea & $14213 e$ & $15499 \mathrm{bcd}$ & $16070 \mathrm{abc}$ & $16583 \mathrm{ab}$ \\
\hline Common vetch & $13633 \mathrm{e}$ & $16418 \mathrm{abc}$ & $16769 a$ & $16237 \mathrm{abc}$ \\
\hline Faba bean & $13620 \mathrm{e}$ & 14618de & $13940 \mathrm{e}$ & $13931 \mathrm{e}$ \\
\hline
\end{tabular}

* Means followed by the same letter are not significantly different at the 0.05 level using the LSD test in each year.

manuring. Although the combined use of green manuring and $360 \mathrm{~kg} \mathrm{ha}^{-1} \mathrm{~N}$ gave an ear yield of $16583 \mathrm{~kg} \mathrm{ha}^{-1}$ in field pea green manuring and an ear yield of $16769 \mathrm{~kg} \mathrm{ha}^{-1}$ with $240 \mathrm{~kg} \mathrm{ha}^{-1} \mathrm{~N}$ in common vetch green manuring, there were no significant differences in ear yield between the 120 and $360 \mathrm{~kg} \mathrm{ha}^{-1} \mathrm{~N}$ treatments (Tab. V).

Ear yield of unfertilized corn following the green legume treatments was similar to that following fallow corn fertilized with $120 \mathrm{~kg} \mathrm{ha}^{-1}$. Based on our data, the fertilizer $\mathrm{N}$ equivalent provided by green manuring crops to the corn was estimated by regression as $110 \mathrm{~kg} \mathrm{ha}^{-\mathrm{P}}$ for common vetch and faba bean and $144 \mathrm{~kg} \mathrm{ha}^{-1}$ for field pea. These findings are in accordance with the results obtained by several researchers (Adams et al., 1970, Ebelhar et al., 1984, Mitchell and Teel, 1977, Utomo et al., 1990) who found that corn yields after annual green manure crops were greater than corn even where as much as 90 to $180 \mathrm{~kg} \mathrm{ha}^{-1} \mathrm{~N}$ had been applied to the soil. Total $\mathrm{N}$ (aboveground and roots) incorporated into the soil from green manuring legumes varied from $34.1 \mathrm{~kg} \mathrm{ha}^{-1}$ for faba bean to $70.7 \mathrm{~kg} \mathrm{ha}^{-1}$ for field pea; whereas, yield increases were equivalent to $110 \mathrm{~kg} \mathrm{ha}^{-1}$ for common vetch and faba bean and $144 \mathrm{~kg} \mathrm{ha}^{-1} \mathrm{~N}$ for field pea. As indicated by Miller and Heitchel (1995), N recovery following green manure crops may vary due to the amount of $\mathrm{N}$ fixed, mass of plant material incorporated, rate of decomposition and immobilization of legume $\mathrm{N}$ in the soil. In this study, we did not measure these amounts, only the total $\mathrm{N}$ content of the above- and belowground biomass. It is not possible to separate these $\mathrm{N}$ sources which may have contributed to these yield increases. However, it is clear that the green manuring legume crops fixed a considerable amount of $\mathrm{N}$ during development and increased mineralization of indigenous soil $\mathrm{N}$ for the following crops during plant development.

\section{CONCLUSION}

This study shows that annual legumes have a good potential as green manure crops in place of fallow in sweet corn production in a Mediterranean-type climate. Field pea and common vetch were the most suitable species for green manuring uses and resulted in high ear yields of corn with limited $\mathrm{N}$ fertilization. Our results also indicated that $\mathrm{N}$ fertilizer application to sweet corn can be reduced by $120 \mathrm{~kg} \mathrm{ha}^{-1} \mathrm{~N}$ if it is preceded by green manuring of annual legumes.

Acknowledgements: The authors wish to thank Prof. Dr. W.L. Hargrove, Kansas State University, Manhattan, USA and Prof. Dr. D.W. Meyer, North Dakota State University, Fargo, USA for critical reading of the manuscript and their valuable comments. This research was supported by the Uludag University Research Fund (2001/26). 


\section{REFERENCES}

Adams W.E., Morris H.D., Dawson R.N. (1970) Effects of cropping systems and nitrogen levels on corn (Zea mays) yields in the Southern Piedmont Region, Agron. J. 62, 655-659.

Aydogdu L., Acikgoz E. (1995) Effect of seeding rate on seed and hay yield in common vetch (Vicia sativa L.), J. Agr. Crop Sci. 174, 181187.

Badaruddin M., Meyer D.W. (1990) Green-manure legume effects on soil nutrition, grain yield and nitrogen nutrition of wheat, Crop Sci. 30, 819-825.

Biederbeck V., Bouman O., Looman J., Slinkard A., Bailey L., Rice W., Janzen H. (1993) Productivity of 4 annual legumes as green manure in dryland cropping systems, Agron. J. 85, 1035-1043.

Davies D.R., Berry J.G., Heath M.C., Dawkins T.C.K. (1985) Pea, in: Summerfield R.J., Roberts E.H. (Eds.), Grain Legume Crops, Collins Professional and Tech. Books, London, pp. 147-198.

Ebelhar S.A., Frye W.W., Blevins R.L. (1984) Nitrogen from legume cover crops for no-tillage corn, Agron. J. 76, 51-55.

Grewal H., Kolar J., Kang J. (1992) Effect of combined use of greenmanure and nitrogen on the productivity of maize (Zea mays) wheat (Triticum aestivum) system, Indian J. Agron. 37, 635-638.
Haynes R.J., Martin R.J., Goh K.M. (1993) Nitrogen fixation, accumulation of soil nitrogen, and nitrogen balance for some field grown legume crops, Field Crops Res. 35, 85-92.

Kahnt G. (1983) Grün-düngung, DLG-Verlag, Frankfurt.

McGuire A.M., Bryant D.C., Denison R.F. (1998) Wheat yields, nitrogen uptake, and soil moisture following winter legume cover crop vs. fallow, Agron. J. 90, 404-410.

Miller D.A., Heitchel G.H. (1995) Nutrition metabolism and nitrogen fixation, in: Barnes R.F., Miller D.A., Nelson C.J. (Eds.), Forages, Iowa State University Press, Ames, Iowa, pp. 45-53.

Mitchell W.H., Teel M.R. (1977) Winter-annual cover crops for no-tillage corn production, Agron. J. 69, 569-573.

Schoth H.A., McKee R. (1966) The vetches, in: Hughes H.D., Heath M.E. Metcalfe D.S. (Eds.), Forages, The Iowa State University Press, Ames, Iowa, pp. 205-210.

Utomo M., Frye W.W., Blevins R.L. (1990) Sustaining soil nitrogen for corn using hairy vetch cover crop, Agron. J. 82, 979-983.

Uzun A., Acikgoz E. (1998) Effect of sowing season and seeding rate on the morphological traits and yields in pea cultivars of differing leaf types, J. Agron. Crop Sci. 181, 215-222.

Uzun A., Bilgili U., Sincik M., Filya I., Acikgoz E. (2005) Yield and quality of forage type pea lines of contrasting leaf types, Euro. J. Agron. $22,85-94$ 